\title{
Barry Herman*
}

\section{A Role for Legitimacy in Sovereign Debt: A Review Essay on Odette Lienau, Rethinking Sovereign Debt, 2014}

DOI 10.1515/ael-2015-0017

Published online June 1, 2016

\begin{abstract}
The book under review seems especially relevant to the intergovernmental policy dialogues that have recently focused on how creditors and a borrowing government should vet sovereign borrowing, and how to hold the lender and borrower accountable for their decisions. The book seeks to specify under what circumstances, if any, there are limits to the legal obligation to repay a sovereign loan. While repayment is always required except in cases of sovereign insolvency when it is just not possible, there have been exceptions to absolute repayment obligation in practice and in legal theory. This review builds on the author's analysis of determinants of illegitimacy (which would remove the obligation to repay) in order to examine why governments in fact repay their loans, why the loss of access to credit makes repudiation of odious loans rare, and how if enforcing the obligation to repay were restricted to "responsible" lending and borrowing under internationally agreed terms, it could advance socially and environmentally sustainable development, while maintaining normal financial market activity of sovereigns. Finally, complementing a loan-byloan approach, this paper calls for an internationally concerted process for more effectively and fairly resolving sovereign insolvencies.
\end{abstract}

Keywords: sovereign debt, odious debt, international law

\section{Table of contents}

1 Who borrows and who lends?

2 Willingness to lend to sovereigns and the nature of repayment obligations

2.1 Sovereign continuity

2.2 Contingent sovereignty

3 Why sovereign borrowers repay

4 Why repudiation is a rare event

5 From odious to responsible lending and borrowing

6 Let us not forget insolvency

References

*Corresponding author: Barry Herman, The New School, Milano School of International Affairs, Management and Urban Policy, New York, NY, USA, E-mail: hermanb@newschool.edu 


\section{List of Symposium Papers}

1 “A Symposium on Sovereign Debt and Reputation” by Odette Lienau

2 "Sovereign Debt Restructuring, Refinancing and the Financial Market: A Comment on Lienau's 'Rethinking Sovereign Debt'” by Yuri Biondi

3 "The Rise of the Notion of Illegitimate Debt: a Comment on 'Rethinking Sovereign Debt: Politics, Reputation, and Legitimacy in Modern Finance' by Odette Lienau” by Tomoko Ishikawa

4 “A Role for Legitimacy in Sovereign Debt: A Review Essay on Odette Lienau, 'Rethinking Sovereign Debt" by Barry Herman

5 "Rethinking Sovereign Debt: Pleading for Human Rights, the Rule of Law, and Economic Sense" by Kunibert Raffer

6 "Embedded Contracts and a Continuum of Sovereign Debt" by Odette Lienau

I have just finished reading a compelling book, Rethinking Sovereign Debt: Politics, Reputation and Legitimacy in Modern Finance by Odette Lienau. I have underlined so much of it that I have probably exhausted its resale value. No matter. I intend to keep it on my shelf. It is rich in theoretical argument and historical illustration.

The book may speak to different readers for different reasons. To this applied economist working on international economic and financial policy issues, especially in a North-South context, the book seems especially relevant to the intergovernmental policy dialogues that have recently focused on how creditors and a borrowing government should vet sovereign borrowing, and how to hold the lender and borrower accountable for their decisions. The book seeks to specify under what circumstances, if any, there are limits to the legal obligation to repay a sovereign loan. While repayment is apparently now considered always obligatory, there have been exceptions in practice and in legal theory, such as, when a new "state" replaces a predecessor "state" that had borrowed funds "illegitimately". The bulk of the book examines these and other cases that challenge the presumption of a mandatory repayment obligation.

Professor Lienau examines how the current legal consensus that governments must always repay their creditors came to be. She contests that consensus, but even if the establishment's legal case withstands her criticism, some philosophers argue that there are occasions in which a government "ought" not honour an "obligation" to repay, even if it is legally binding; at other times it might honour the obligation and at still other times it definitely should honour it; and equally, there are occasions in which the creditor should not demand repayment even if the borrower is legally obligated, may demand repayment and should demand repayment (Barry \& Tomitova, 2007). Professor Lienau's discussion of the cases in which the sovereign's requirement to repay was challenged is thus of interest to sovereign debt policy "wonks" as it asks us to consider what 
criteria should define when a sovereign loan should or should not have to be repaid, thus opening the discussion to what defines "responsible" - a related but more compelling term than "legitimate" - sovereign borrowing and lending to sovereigns.

In other words, Professor Lienau's book is of political interest. Failing to repay an "odious" loan might be popular in the debtor country. Creditors who made such loans might also have difficulty mobilizing political support for their claim for repayment. Indeed, the financial community might not react negatively if a government decides not to repay a loan that qualifies as "odious" or "irresponsible" according to some agreed definition. Thus, while some readers may focus on the book's legal attack on the assumption of "debt continuity" within the context of contract law, this reviewer sees it as an argument for creating an intergovernmental arrangement to qualify contract law on the enforceability of specific repayment obligations. ${ }^{1}$ Such an intergovernmental arrangement could also help address a separate issue, namely how to resolve sovereign insolvencies, i.e., overall inability to make interest and principal payments as they fall due, a question this paper briefly addresses in the concluding section.

\section{Who borrows and who lends?}

Before introducing Professor Lienau's argument, it might be useful to set the stage with a quick characterization of the different purposes of government borrowing and the creditors that lend to them.

It is a trivial statement to say so, but governments borrow because they need the money. They regularly borrow, first of all, from their own residents as a normal aspect of governing. They borrow short term (e.g., to cover the cost of ongoing expenditures in anticipation of quarterly tax revenues), medium term to cover a budget deficit, and long term to invest in infrastructure. Some infrastructure projects will repay creditors out of revenues collected from future users of a service, such as tolls for crossing a bridge. In other projects, where it is not practical to charge beneficiaries, such as for use of city streets by automobiles, bicycles and pedestrians, payment will be made out of general tax revenues. It is reasonable to ask the future as well as the current beneficiaries to pay those taxes. In both

1 One might say there are already at least implicit limitations on enforceability, as for contracts involving money laundering or terrorist financing. The proposal below will be to establish a broader range of such limitations. 
infrastructure cases, the construction cost is covered up front by the borrowed money, warranting public debt financing of the investment outlays. ${ }^{2}$

Most governments (or their central banks), especially of developing countries, also regularly borrow in the international market because that is where they can acquire foreign currency and because there is usually a deeper pool of loanable funds in the international market than exists in the domestic market. Often, a government will pay a lower interest rate on bonds issued in foreign currency in the international market than on a domestic currency bond issued at home. One reason is that the borrowing government cannot inflate away its obligations denominated in another country's currency; governments can default on their foreign debt, but they rarely do. The international market in sovereign bonds functions on just that expectation.

Some international lending to sovereigns is provided outside the market by public authorities, either by other governments or multilateral institutions owned, controlled and funded (at least in part) by governments, such as the International Monetary Fund (IMF) and the World Bank. While the lender's motivation in those cases is drawn from its policy regime, public lenders do insist on being repaid. If they were indifferent to being repaid, they would extend the financing as a grant, which in fact many do when providing resources to developing countries for several purposes, such as food aid or technical assistance (provided as cash or commodities or expertise). Nevertheless, public lenders will override their demand to be repaid in the face of more urgent policy or political considerations. ${ }^{3}$

The multilateral financial institutions operate in particular ways. IMF is essentially a credit union of its member governments, as it mainly lends out funds that they have deposited. It provides general purpose loans to governments; it is the overall "lender of last resort" to governments. The development banks lend for projects and programs and with longer maturities than available to most developing countries from private finance. The development banks assemble their funds mainly by issuing bonds in the international market that are guaranteed by their government shareholders. Repayment of the IMF and development bank loans has been informally accorded the highest priority and has been virtually a condition for any financial interaction with the official financial community. That priority is

2 In fact, there are multiple ways to finance infrastructure investment, only some of which involve traditional direct borrowing by governments (see Mody, 1996).

3 For example, government creditors that cooperate in the Paris Club have unilaterally offered to postpone payments falling due from countries impacted by tsunamis or other shocks (for details, see http://www.clubdeparis.org/en/communications/page/exceptional-treatments-incase-of-crisis). 
accepted by the other public and private creditors because the multilateral institutions lend to the countries when private finance won't.

Today, despite the growth of private international finance, multilateral official lending remains an important source of funds for many developing countries and for some specific purposes. Even developing countries that are able to borrow directly from the international financial market usually also draw on international public finance for some of their needs. For example, for some borrowers, long-term finance from the private sector sometimes takes the form of co-financing with the public institutions, whose involvement raises confidence of private investors in the soundness of the projects being financed.

Nevertheless, most borrowing governments increasingly draw their external credits from international private finance and on a purely commercial basis. Until recently, only middle-income and upper-income countries could "float" bond issues on the international market, but low-income countries, sometimes called "frontier markets" by the financial industry, are increasingly also tapping this source of financing. Moreover, the international bond market is expected to be a growing share of international sovereign borrowing in future years.

In the 1970s and 1980s, the form of cross-border borrowing that dominated the sovereign debt market was commercial bank loans to governments, made either by individual banks or through syndicates that could sometimes involve 500 banks. Some of those banks had business interests in the countries to which they were lending; for others, it was a purely financial investment. This created different interests among the banks in the syndicates and a market arose in the 1980s for trading participations in these syndicates by the banks that had primarily a financial interest in the operation. Since the 1990s, investment banks have been the main intermediary between the borrowing government and foreign private finance, helping governments to design and then sell an issue of its bonds to foreign buyers. Unlike the commercial banks that actually made loans, the investment bank's relationship with the borrower does not extend beyond the underwriting of the bond, except in so far as it may be hired to help float future issues.

Usually, thousands of investors - mostly institutional investors, such as insurance companies, pension funds, large commercial banks, mutual funds, hedge funds, etc - buy any given bond issue and it is uncommon for the investors to hold them to maturity. ${ }^{4}$ As market conditions change, they will

4 Individuals also buy bonds and usually hold them long term, but they are much more in the minority of bond investors than in past eras as individuals now have the option of spreading risks through mutual funds. 
sell them and purchase other bonds with different currency, interest rate and maturity characteristics. From the bondholder's perspective, the bonds are purely financial instruments that are included for a time in the investor's portfolio. There is probably little thought given to the ethical nature of the government that issued the bond or how the funds were used one, five or ten years earlier when they were actually borrowed.

This could change as growing parts of the "buy side" of international finance become more sensitized to the social and environmental consequences of the investments financed. Although "responsible" investors seem to represent only a small minority of the financial market today, the fact that major financial institutions and other large corporations announce their adherence to self-styled codes of social and environmental responsibility suggests that there is a nascent constituency for making finance more responsible. ${ }^{5}$ In the end, this cannot be addressed by voluntary adherence to different codes. It is a typical "collective action" problem that requires national legislation and international agreements. We return to this discussion later.

\section{Willingness to lend to sovereigns and the nature of repayment obligations}

The kernel of Professor Lienau's argument is that legal repayment obligations of sovereign borrowers can be thought of either as contingent or as absolute, depending on the governing concept of sovereignty. She believes they are in fact considered to be absolute - indeed, a reason that creditors are willing to lend to them - but should be considered contingent. As she relates in the first chapter of the book, the relevance of different concepts of sovereignty to repayment of sovereign debt is most easily seen in the debates about "odious" debt. These debates were revived some years ago by international civil society organizations that advocate for the poor in developing countries (e.g., see Christian Aid, 2007). The argument put forward by the civil society organizations concerns the case when creditors lend to a foreign government for uses that do not reflect the expressed interest of the people and instead harms them. When the creditors know that intention at the time of making the loan, the debt should be deemed illegitimate and repayment should not be required even though responsible

5 For example, see Deutsche Bank's social responsibility web page at https://www.db.com/cr/ index_en.htm. The World Bank Institute's corporate social responsibility program collected 28 industry or business-sector codes at http://go.worldbank.org/PS46XZGJZ0. 
officials of the government at the time signed the loan contract. This is the classic “odious debt” argument of Alexander Sack (1927).

\section{Sovereign continuity}

The contrasting concept, she posits, is that a sovereign state is deemed always responsible for its debts, no matter why they are undertaken or whether undertaken by the current or previous regimes or even by predecessor states, as long as the government was in control of the country when the loans were signed. ${ }^{6}$ In other words, pacta sunt servanda (agreements must be honoured). The only exception is when governments cannot pay, which is to say, when they become "insolvent." Facing that reality, creditors may perforce agree to postpone or reduce debt repayments, but that they are actually owed is not questioned. The reader may guess that creditors prefer this latter concept to the odious debt doctrine. Professor Lienau goes a step further and asserts that the creditors and the governments feel the principle is essential to a well-functioning international sovereign debt market. In other words, the fact that courts or arbitrators stand ready to apply the pacta principle is considered an essential reason that creditors are willing to lend.

The underlying reasoning it is considered essential begins by drawing a contrast with lending to private borrowers. In that case, a loan may include collateral that the creditor will possess if the borrower defaults. Also, the creditor can take the private borrower to court to enforce the loan contract whether or not there is collateral. However, both going to court and collecting collateral are costly, and bankruptcy protection limits how much the lender can obtain when the borrower is insolvent. Thus, borrowers with higher risk of default pay higher interest rates for their loans to compensate the lender for its risk of loss.

Lending to sovereigns is usually without any pledge of collateral and even if a court awards overdue repayment to a creditor, it may be difficult to collect on that award if the sovereign refuses to pay. Thus, legal remedies for non-payment are uncertain. Pacta sunt servanda is said to make them less uncertain because

6 The obligation to repay the debts of predecessor states has long been contested. While creditors generally insist on repayment by the successor government, there are successful cases of repudiation; e. g., the United States formally repudiated through the Fourteenth Amendment to the US Constitution the debts of the Confederacy of slave states that had been defeated in the civil war and were now reintegrated into the United States (Lienau, p. 241n). As will be noted below, the young Soviet Union repudiated the czarist debt it inherited but ultimately "un-repudiated" it in two steps, first as USSR (1986) and then as the Russian Federation (1996). 
all creditors take it as a given, would frown on any violation, and debtors appreciate that. Thus, although riskier sovereign borrowers are asked to pay a higher interest rate than less risky ones, sovereigns almost always pay lower interest rates than corporate or other private borrowers. Apparently, creditors believe that sovereigns actually accept the obligation to repay. Creditors also believe that sovereigns can almost always use the power of the state to mobilize the funds for repayment from their citizens. They thus almost always have the ability to pay. Even when they do not have that ability, i. e., when they are insolvent, creditors will collect something from the sovereign debtor, whether from a voluntary negotiation or arbitration or a court decision somewhere.

Professor Lienau refers to this approach as the "statist" conception of sovereignty, or "sovereign continuity". A comment may be warranted on its nature. It is apparently seen in the legal profession as an application of a broader concept of pacta sunt servanda, which seems to have important political value. Signatories of the Treaty on the Non-Proliferation of Nuclear Weapons, for example, are assumed to remain bound by the treaty even if their governments change, and independently of whether the change resulted from elections or coups d'état or revolution. The government of the Shah of Iran became a party to that treaty in 1970 and the current Iranian government has not withdrawn from it. Indeed, much of the pressure on Iran in recent years has been couched in terms of raising confidence in its continuing commitment to the peaceful uses of nuclear energy as per the treaty. Recognized successor states are also held to be bound by the treaties that had been signed by the responsible authorities of the predecessor state; e. g., the Russian Federation became the relevant partner in the Non-Proliferation Treaty as it declared itself the legal successor to the Soviet Union.

Perhaps the financial industry assumes that because the world applies pacta sunt servanda to the continuity of treaties that it should apply equally to financial contracts. I think Professor Lienau would call that an error. Indeed, while there is a Vienna Convention on the Succession of States in Respect of Treaties, there seems to be no consensus statement on the succession of states for non-treaty matters (Lienau, p.174). And so, there is an opening for international law to apply the more nuanced view that is encapsulated in the odious debt doctrine, even if the financial community finds the statist one attractive. The modified pacta concept might be stated as all debt contracts that satisfy certain criteria must be honoured. Someone would have to certify that those criteria were met. It could be a judge in the home country of the unhappy private creditors, following some sort of explicit international guidance, which means there would need to be some sort of international guidance (that guidance would presumably also apply in some form to 
repayment of public creditors). Furthermore, although she does not develop the point, the financial market would adapt to whatever standard became international law. They might fight it, but then they would live with it and operate within it.

\section{Contingent sovereignty}

And here comes Professor Lienau's challenge: under existing law and practice, if a debtor government alleged a loan to be odious and repudiated it, would a court in the creditor's country judge that sovereign to be obligated to repay the loan anyway? Would a court actually try to force a legitimate government - or more precisely, its taxpayers - to repay an odious loan? In an arbitration case discussed in detail in the book involving obligations of Costa Rica created by a subsequently departed dictator, Federico Tinoco, the answer was no, the government did not have to repay that debt. If the creditor had been the British government instead of the private sector Royal Bank of Canada that the British government represented in the case, it might have been swayed by the fact that the loan had no public purpose and waived repayment as an aspect of its foreign policy. But that's politics, not law. Instead, the British government sought full repayment on behalf of the creditor after Costa Rica repudiated the loan. Both sides agreed to submit the case to arbitration for a binding decision. The arbitrator was William Howard Taft, former U.S. President and recently appointed Chief Justice of the U.S. Supreme Court. Taft found it acceptable for Costa Rica to repudiate that particular loan. That, however, was 1923. Professor Lienau believes the statist conception that is currently dominant in international law would lead the judge to ignore the odious debt claim.

In another case analyzed in detail, no international tribunal or arbitrator evaluated odiousness claims; instead, a state unilaterally repudiated on odiousness grounds all the loans taken by its predecessor state. The government of the new state did promise to repay - and did repay - its own obligations, but not those of its predecessors. The case is that of the Soviet Union in the 1920s, a time of post-war resurgent international lending, involving in part new American entrants to the international market and an active trade finance sector in Europe. These financial institutions were interested in extending loans to the communist regime, while older financial institutions holding repudiated czarist bonds abhorred the idea.

The message Professor Lienau draws from the Soviet case is that in a dynamic and competitive market, at least some creditors will lend even to a 
government that asserts what might be called "sovereign discontinuities". The implicit argument is that some creditors will be willing to take risks to build their portfolio in the market despite the less-certain legal standing of their claims against the sovereign borrowers. Bond buyers have rarely been accused of reading the "boilerplate" clauses of the contracts. Nevertheless, private creditors will only lend if they feel confident of repayment. The Soviet case involved trade finance, which is special as it embodies implicit collateral, as the need to trade continues. However, there are certainly cases of lending by public creditors to a sovereign debtor in the face of its non-payment of earlier creditors. These cases have political and economic motivations, such as Venezuelan and Chinese lending to the government of Argentina during the Kirchner administration's refusal to negotiate repayment with its "vulture" creditors. $^{7}$

Isolated cases aside, Professor Lienau is proposing that the odiousness argument be taken seriously. If accepted, would it throw a monkey wrench into the overall market willingness to lend? If debts must be honoured only if they pass a legitimacy test, how much more due diligence must lenders do before making the loan? That question can be answered, although it would take an international agreement to give the answer legal effect. Certainly, forprofit lenders would build the cost of the extra due diligence into the interest rate, as well as the heightened risk of non-payment if their due diligence were inadequate. With that caveat, the international sovereign debt market should survive, although it might be a bit smaller than under the existing legal standard. Is that a bad outcome?

Professor Lienau goes on to consider how to formulate the additional due diligence, in particular, by asking if the government is the legitimate "agent" for the population of the country, who are its "principals". This may not be the only due diligence question to ask, but it is a place to start. She thus identifies alternative conceptions of legitimacy based on historical precedence that could confirm the obligation to repay. One conception she calls "rule of law sovereignty", in which the government would be deemed legitimate because it follows laws it has established. Another is called "popular sovereignty", in which government actions reflect the consent of the governed, and the third is

7 There is, nevertheless, a lesson in the success of NML Capital and other "vulture" funds in stopping Argentine payments to its other bondholders while their bonds were unpaid. It means that the new risk-taking lenders (public or private) would have to take care that repayments of their new loans would lie outside the usual circuits of international finance where they could be attached by the earlier creditors. 
"outcome orientation sovereignty", where the government produces acceptable outcomes regardless of its process of internal rule. Each of these concepts focuses attention on the inner workings of the government. Presumably, she is thinking that in some case in which an indebted government refuses to repay a creditor on odiousness grounds, a legal forum or arbitration mechanism would ask if any of these three approaches to sovereign legitimacy obtained. The key in all of this is that obligation to repay would not be determined solely by whether or not the government was in effective control of the territory of the country.

The principal/agent approach that Professor Lienau is advancing here is apparently standard in law. However, there is a shortcoming in it, albeit not much discussed, that relates to long-term borrowing. When the same population cohort in whose interest the government takes out the loan also repays it, there is a valid principal/agent relationship, as long as the agent is legitimate and the loan is non-odious. For a medium-term loan, the citizens who repay will include dependent children of adult citizens when the loan is contracted and so one may say that the agent still legitimately represents the principals as the adults can make decisions for their children (although the "lucky" senior citizens who die will escape repaying). The question becomes more challenging for a long-term loan that will be repaid by citizens not yet born. By what principle is the current government their agent? Who transfers the democratic rights of the unborn citizens to their predecessors? Do those citizens fully owe payment to the heirs of the original creditors? The legal answer is "yes" if the debt contract remains in force. But should it? There is no easy answer and some philosophers, such as Axel Gosseries (2007), have said that we therefore need something other than the principal/agent approach to figure who owes what to whom across generations if we are to reach conclusions about justice in public financial relations. ${ }^{8}$

\section{Why sovereign borrowers repay}

Economists have puzzled for decades over why sovereigns actually repay their loans when enforcement of the loan contracts is uncertain. ${ }^{9}$ One answer is a belief

8 One question that troubled Gosseries can be put in terms of the infrastructure loans mentioned in the beginning of this review: who should pay when no one crosses the bridge anymore or lives in the neighbourhood whose streets were paved a generation before?

9 There are two streams of thought: 1) sovereigns pay because they fear retaliatory sanctions for non-payment and 2) sovereigns want to maintain market access. For a review of the main strains of economic theorizing, see Panizza, Sturzenegger and Zellelmeyer (2009). 
that the sovereign has a very strong motivation to honour its debt obligations, just as individuals have a very strong motivation. Even the experience in the microcredit world validates the latter observation. That is, the group lending made famous by Grameen Bank in Bangladesh as a means to ensure repayment was found to be unnecessary. A Grameen agent would go into a village and promote the idea of women taking small loans to improve their livelihoods. The agent would form the women into small groups of five that would be collectively responsible that each member repaid her loans fully and on time. While this created effective social pressure on the individual borrowers to repay, the women did not like it; it had negative social consequences and other microcredit lenders found it unnecessary. Bank Rakyat Indonesia (BRI), for example, pioneered another approach for its micro lending, which made individuals responsible for repayment of simple-to-understand loans, which they overwhelmingly did. There was a modest financial incentive for prompt repayment, but that did not seem to be the controlling factor. Also, that BRI would take possession of their small farms in the event of non-payment was not a credible threat. Rather, small farmers and traders needed continued access to credit and so maintaining their reputation as responsible borrowers was an effective incentive. Ultimately, Grameen Bank abandoned its group lending strategy. ${ }^{10}$

While governments can (and sometimes do) force domestic financial institutions to lend to them, they need to maintain their reputation for prompt and full repayment to have continued access to foreign borrowing. This is important just to manage their stock of outstanding debt, but it is also important for smooth management of economic cycles. Typically, governments repay maturing debt with new loans rather than reduce the amount of debt outstanding. This requires periodic access to national and international financial markets. If they were to reduce the stock of debt, they would need to run a budget surplus plus have a trade surplus and/or a net foreign private financial inflow to offset the government's payment outflow. Those conditions are fine when the economy is buoyant, tax revenues pour in, exports are strong and foreign investors are interested in the country.

Equally, however, when the economy is weak and slipping into recession, governments want the ability to borrow abroad to supplement the availability of foreign currency and budget resources. Usually, when private lenders or bondholders begin to have doubts about the willingness or ability of a sovereign debtor to repay, they begin withdrawing their funds, or in current market parlance, they reduce their "long position" as a net creditor of the country.

10 See the chapters on "Group Lending" and "Beyond Group Lending” in Armendáriz and Morduch (2010). For further discussion of the operation of "relationship" banking in credit unions and other alternative banks, see Butzbach and von Mettenheim (2015). 
The market will see this in reduced prices and higher yields of the government's bonds in the market, which will signal "sell" to other investors. As "herd behaviour" is common in financial markets, there will be further and perhaps cascading withdrawals. ${ }^{11}$ The distrusted government will be then confronted with a higher cost of borrowing, if not a loss of access to credit. Such a loss of confidence will then impose a contractionary impact on the economy through the balance of external payments and the budget. Depending on the degree of lost confidence and the speed with which the stock of foreign exchange reserves is being run down to maintain external payments, and without other offsetting changes, incomes would have to fall and unemployment rise.

In addition to this kind of countercyclical borrowing, governments also want to have the ability to undertake net new borrowing for long-term projects that only pay for themselves over time, as noted before. Borrowing denominated in foreign currency is especially useful when there is a substantial foreign component of the project's investment expenditure (e. g., building a desalination plant where most of the equipment needs to be imported) or when the project will earn foreign currency with which to repay the loan (e.g., expanding an airport to handle tourist inflows). Again, as also mentioned above, it may be cheaper for a government to borrow abroad than to borrow from the domestic market.

It should be clear, in other words, that it is very useful to a government - virtually essential for a developing country - to retain its reputation as a responsible borrower. Governments thus almost always repay their debts in full, at least their foreign debts. That is, sometimes they repay their domestic debts incompletely, as when inflation reduces the purchasing power of the funds repaid. ${ }^{12}$ Inflation is not an option with foreign-currency denominated debt and great efforts are typically made to avoid default. Suffice it to say here that the debtor government that does become insolvent will usually work with its private and/or public creditors and the IMF to arrange a "cooperative" restructuring of the obligations. The government will seek to minimize the time it loses access to finance from abroad.

11 In addition to selling their government bonds, the foreign investors might buy credit default swaps (CDSs) if the debtor country was big enough for a market in those swaps to arise. The loss of confidence in the country would also be reflected in the increased demand for those CDSs, as they pay the holder if the government defaults.

12 Adam Smith famously complained about inflation as a method of disguising public bankruptcy, not only because it reduces the real value of payments to the government's creditors, who are "the greater part of them, wealthy people" (for whom he apparently felt only some sympathy), but also "extends the calamity to a great number of other innocent people", the real value of whose assets are diminished, rewarding only the "idle and profuse debtor at the expense of the industrious and frugal creditor" (Smith, 1776, pp. 882-883). The irony is that business activity, even in Adam Smith's day, especially international trade, ran on credit. 
Indeed, loss of access is costly, as the experience in Argentina shows. It faced many years of exclusion from being able to issue new international bonds owing to the litigation in the U.S. courts by a group of speculative "vulture funds". ${ }^{13}$ That dispute was not about odious debt and did not entail denial of the validity of creditor claims. It was only about how much to pay the vulture investors, who bought already-defaulted bonds on the secondary market at deep discount and never actually lent to Argentina. The market and the U.S. courts frowned on what they saw as Argentina's intransigence in not settling with the vultures. Argentina saw itself upholding a principled position, which is that the vultures should accept the same repayment terms as agreed by $93 \%$ of the other holders of its bonds from its pre-crisis period. The U.S. courts also sympathized with the vultures' unique attempt to capture Argentine funds as they moved through U.S., European or even Argentine banking circuits. To avoid paying the vultures at the expense of other bondholders, Argentina had to stop making its interest payments on its outstanding bonds. ${ }^{14}$

Thus cut off from international financial market borrowing, Argentina needed even more than other countries to have a large stock of foreign currency to use in case of need. It had built up its foreign exchange reserves and paid off its borrowings from the IMF during its first decade of recovery from its crisis. In more recent years, as the economy weakened, it has been drawing down its reserves. It has also taken loans from lenders outside the financial mainstream, such as China's national development bank (Reuters, 2014). Although Argentina has thus coped with its loss of access to international private finance, it has had to postpone some investments. Indeed, the successor Argentine government, which took office in December 2015, settled with its vulture fund creditors in less than three months and was expected to soon re-enter the financial markets with a new bond issue.

Argentina is a big country; other countries have had to sacrifice more in a similar situation, including substantial payments to the litigating investors, not to mention court costs and lawyers' fees. Indeed, most debtor country governments give up and settle with vulture funds after courts in creditor countries give

13 Argentina has also faced creditor attacks through arbitration under its bilateral investment treaties, a distortion of the intent of those treaties, which are meant to constrain acts of a sovereign government against direct investors in its economy and not foreign "commercial" transactions of the sovereign such as are embodied in its bonds issued on international financial markets (Ichikawa, 2014).

14 The legal literature on this case is vast, including amicus curiae briefs before US appellate and supreme courts by the US, French, Brazilian and other governments; for a non-technical exposition, see Salmon (2014). See also Ishikawa (2015). 
them a sympathetic hearing. ${ }^{15}$ They very much needed the returned access to external investors and creditors.

\section{Why repudiation is a rare event}

A decade ago, civil society organizations were using the odious debt argument to address the problems of countries with excessive debt burdens. This seems to have abated in recent years, I think because the argument did not advance advocacy for sustainable debt. In addition, most developing country governments have not wanted to make the claim that the debt they owe is odious. This was most obvious in South Africa after the end of apartheid. As discussed by Professor Lienau (pp.191-192), the African National Congress decided the government should fully service South Africa's inherited debt, a good portion of which could legitimately have been scored as odious. South Africa had the capacity to service the debt and did not want to take any step that would impede its access to international financial markets, nor raise concerns in the already nervous white population as to the continuity of basic economic relationships.

In another case, civil society organizations could only have been disappointed by their experience in Ecuador. They helped to produce a comprehensive audit of Ecuador's sovereign debt at the invitation of President Rafael Correa, who had campaigned for the office in part on the basis of the illegitimacy of the debt. The government then ignored the audit commission's findings and opportunistically defaulted on two external bond issues, as Professor Lienau discusses in detail (pp. 215-222). That was in December 2008 when the international financial markets were fully distracted by the global financial crisis. The default drove down the market price of the bonds, which Ecuador then bought up during 2009 at about 35 cents on the dollar. It was a clever move by President Correa (although the cash outflow was much more than the interest payments would have been). But odiousness was irrelevant to the actions that Ecuador took. ${ }^{16}$

15 Winning a case has been highly profitable for the litigants (see Schumacher, Trebesch \& Enderlein, 2014, appendix 2), as it has been highly costly for countries, such as Cameroon, Democratic Republic of Congo, Liberia, Peru and Zambia (see http://www.jubileeusa.org/our work/vulturefunds.html\#sthash.8y2JZi8x.dpuf).

16 Although the rhetoric from Ecuador claimed that the two bond issues were illegitimate (Lineau, p. 217), two factors point to its irrelevance: 1) the two bond issues were deemed neither more nor less odious than a third issue on which the government decided not to default; and 2) the bonds were not repudiated, but rather the government paid about $\$ 1$ billion to repurchase and retire them at the going market price (Porzecanski, 2010). 
The international treatment of the Soviet insolvency in the early 1920s is also instructive. After the destruction of the First World War and the subsequent civil war aiming to unseat the Bolsheviks, it was clear to all that the government was insolvent. On top of this, however, the USSR repudiated the czarist debt. The creditors offered to renegotiate the debt, but the Soviet government refused. Professor Lienau calls repudiation a costly step. While renegotiation would have required some debt servicing payments instead of none and return of confiscated foreign assets or payment of compensation for them, repudiation did cause loss of access to general foreign financing and to czarist assets frozen in British banks, although exporters in various countries still arranged trade credits, as she details.

Moreover, repudiation had been a publicly announced intention of the Bolsheviks as early as 1905 and so delivering on that promise was politically important (as it was to President Correa in Ecuador). In addition, Stalin sought to minimize dependence on foreign finance, if at considerable domestic human and economic cost. Although it borrowed in the latter 1920s and during and immediately after the Second World War, the country did not otherwise seek to borrow until the 1970s. Subsequently, it "unrepudiated" the czarist bonds held in the U.K. in 1986 and in France in 1996. In the end, in other words, the USSR and the Russian Federation as successor state to most of the territory of the USSR decided to recognize the validity of the czarist debt in order to return to borrowing on international markets. In fact, anxious to facilitate Russia's return to the financial markets, the U.K. and French governments settled the obligations for pennies on the dollar. ${ }^{17}$

\section{From odious to responsible lending and borrowing}

It should be noted that Costa Rica was not insolvent when it repudiated the Tinoco loan. It continued to service its other debt and it was not excluded from the financial markets. The controversy was about an irresponsible loan provided by an irresponsible lender to an illegitimate sovereign. That in itself speaks to a current international policy concern noted earlier, namely would it be possible

17 That is, Moscow paid only a small fraction of the value of the bonds when it settled with the U.K. by swapping its claim on the Czar's gold held in British banks for the claims of Britons on Russia, in effect paying about $10 \%$ of the bonds' value, and it paid France $\$ 400$ million to cover the bonds and property claims of the French, or about $1-2 \%$ of those claims (SinyaginaWoodruff, 2003). 
to introduce ex ante conditions on financial transactions of sovereigns in order to strengthen economic, social and environmental policies and behaviours of countries? Loans that satisfy the ex ante conditions might carry an identifier so that any investors adding such a bond to their portfolios would be assured that pacta applied to it; even without legal assurance, it seems that voluntary labelling might be a useful indicator to some classes of investors. The chief point is that non-payment of an uncertified debt should not provoke a general exclusion of the debtor government from the international bond market.

A first condition in this regard might be that "debt continuity" should be honoured only for countries deemed "appropriately" sovereign. For example, the international community acting through the United Nations has grappled with whether the sovereignty of states should always be respected or whether there are situations of such gross human rights abuse that the community of nations is justified in intervening militarily in the country, which is a violation of its sovereignty. Humanitarian intervention has long been given as a reason for one country to invade another. ${ }^{18}$ More often, the world just watches atrocities unfold. However, the international passivity during the Rwandan genocide in 1994 prompted efforts to codify when military intervention was warranted. A concept called the "responsibility to protect" was thus elaborated as justification for military intervention (Orwin, 2006). However, in light of the disappointing outcome of UN interventions undertaken subsequently, as in Libya, there seems less enthusiasm to apply this principle to other cases. Nevertheless, the idea survives that states need to deserve the sovereign respect of their peers.

In fact, the UN Security Council has also acted against countries for reasons other than humanitarian exigencies. A case in point was Iraq's invasion of Kuwait in August 1990, in response to which the United Nations imposed broad economic sanctions on Saddam Hussein's regime and then militarily forced Iraq to retreat back to its borders in 1991. However, the sanctions remained and gathered criticism for hurting the population at large and not the officials of the regime who were largely able to evade them. This sharpened recognition of the need to better target sanctions so as to hurt the regime and not the people. One concern was to find a way to decide which financial and trade relations to permit and which to prohibit. Although this problem cannot be said to have been solved, there have been some interesting proposals. Some principles might be formulated, for example, by which an authority could

18 A famous case in point is the US invasion of Cuba in 1898, which gave rise to a famous odious debt case in which the US refused to repay loans that Spain had extended to its Cuban colony on the grounds that they were used to repress the Cuban people. Of course, one is welcome to be skeptical about the actual motivation for the US intervention. 
distinguish an odious from a non-odious loan proposal for an officially-declared odious-prone regime, coupled with assurances that any financial institution extending a loan declared odious could not count on the courts to help it collect repayment and/or it could risk being taken to court by its home authorities for violating the sanctions regime. ${ }^{19}$

These extreme political interventions aside, international involvement in the domestic economic policies of developing countries is a regular feature of developing country relations with the multilateral institutions. The IMF and the multilateral development banks regularly peer into the domestic workings of developing country governments in evaluating loan proposals and demand policy changes as conditions for extending loans. Moreover, as Professor Lienau discusses (pp.196-198), the World Bank, the European Bank for Reconstruction and Development and other regional banks have established economic, social and environmental criteria of benefit that their loans have to meet. They also maintain accountability mechanisms by which people negatively affected by bank projects can bring their concerns to the banks and potentially stop or alter the projects (Bissell \& Nanwani, 2009).

This is, none the less, contested terrain. Borrowing countries have always regarded multilateral "conditionality" as interference in their sovereign right to choose their own domestic policies, although they pragmatically accept the conditions - and the fiction that there was no coercion - to get the loans. Civil society organizations, on the other hand, fight to maintain and strengthen the interventions in country policies on human rights, humanitarian and environmental grounds. Not only can civil society critics legitimately complain about the limited budget allocations by the multilateral banks for ombudsmen investigations and institutional passivity when protesting stakeholders face borrowing government reprisals, but there now are also fears that the institutions intend to roll back what safeguards are applied to which loans (Human Rights Watch, 2015).

There are also initiatives of groups of private financial institutions to specify and implement social and environmental due diligence before making loans, most notably, the Equator Principles for project finance. ${ }^{20}$ It is hard at this point to know the degree to which such efforts of the private institutions - or even the public ones - are serious or are cynically responding to public criticism, a

19 For a proposal on how financial institution due diligence in such a case could be overseen and cleared by an international authority such as the Security Council, see Shafter (2007).

20 Project finance is long-term lending arranged through large financial institutions mainly for infrastructure. For the text of the principles, a listing of the 81 financial institutions that commit to them, and a note on how to implement them, see http://www.equator-principles.com/. 
question that Professor Lienau asks as well (pp.202-203). If some such due diligence by private financial institutions became the standard practice before loans were made and if the loans had to be monitored for adherence to promised standards, and if proof of the due diligence and monitoring were required for legal enforcement of loan repayment, I think sustainable development policy would have crossed from international politics to international law. It has not yet happened, but it might be something to work towards.

Finally, it is worth drawing attention to an initiative noted as well by Professor Lienau. The initiative was undertaken in the Secretariat of the United Nations Conference on Trade and Development (UNCTAD), financially supported by the government of Norway, to define general standards for appropriate behaviour of sovereign borrowers and their creditors (UNCTAD, 2012). The principles are coherent and comprehensive and mainly serve to codify existing practice. In this regard, it is disappointing that they only have the standing of recommendations of an expert group and have not been officially endorsed by the UN General Assembly. However, member states have agreed at the recent International Conference on Financing for Development in Addis Ababa to "work towards a global consensus on guidelines for debtor and creditor responsibilities in borrowing by and lending to sovereigns, building on existing initiatives" (United Nations, 2015a, paragraph 97). ${ }^{21}$ That is an international mandate to work toward standards that governments could embrace and own. It only remains for governments to start responding to the mandate.

\section{Let us not forget insolvency}

This paper noted early on that the rebirth of interest in the concept of odious debt laid with civil society organizations that campaign for relief from excessive debt obligations of developing countries. This paper argued that the current significance of the concept and of the analysis of Professor Lienau lay elsewhere, specifically, in supporting the case for enforceable rules to guide decisions on sovereign borrowing and on lending to sovereigns so as to further the social, economic and environmental aspects of the global commitment to sustainable development that the largest gathering ever of heads of state adopted at the United Nations in September 2015 (General Assembly resolution 70/1).

21 In the same paragraph, the Conference only took note of the UNCTAD principles, among other initiatives. 
Meanwhile, the original civil society concern remains to be addressed about how to support more effective, timely and fair workouts from sovereign debt crises. Unlike a bankrupt corporation, an insolvent country cannot be dismembered and its assets sold. But its people can suffer mightily for the policies and/or bad luck of its government.

There is no hard and fast rule for determining when a country enters the realm of insolvency and needs a process to reduce its debt. One defining characteristic is that the government cannot fulfil its obligations on its debt. Any new borrowing would only reduce the amount of recovery of at least some existing creditors. Thus, if the creditors were to act as a unified group, they would oppose new lending to an insolvent government and demand an appropriately shared reduction in repayment obligations. This does not happen in our decentralized and "market-oriented" system and - as Greece so clearly showed - it has unfortunate consequences, delaying recognition of the problem and adding layers of new obligations that cannot be met.

At the same time, it is not a simple matter to distinguish insolvency from a condition of illiquidity in which the government can no longer draw upon its usual sources of loans owing to loss of confidence in its ability to repay. The usual next step for an illiquid debtor is to approach the IMF for financial assistance while it adjusts its policies or overcomes the "shocks" that have caused the illiquidity. In time, the illiquid debtor is expected to conquer its difficulties and meet all its debt obligations. Sometimes, however, a debtor thought to be illiquid turns out to have been insolvent; then it needs to reduce its debt.

Governments or international public institutions may intervene to help an illiquid government to maintain its debt servicing, albeit in the process substituting public debt for private debt, as in the case of Greece. However, "bailing out" the creditors of an insolvent country (e.g., Greece again) has less popular appeal than "bailing them in" by forcing them to take losses through a negotiated restructuring of the debt. ${ }^{22}$

The standard approach in debt restructuring is for the government to reach separate deals with each of its main classes of creditors. For bonds, the government negotiates an agreement with the holders of each bond issue, usually leading to an exchange of old bonds for new bonds worth less than the old ones. Bank loans are renegotiated with an ad hoc committee of commercial banks, called a London club. The standard practice for restructuring debts owed

22 If the debtor owed illegitimate loans, one might say those loans should be forgiven first, but that is wrong. They should be cancelled regardless of the overall debt situation of the borrowing country. There should be no illegitimate debt going into a debt restructuring. 
to other governments is that those governments meet in their Paris Club and decide how much to adjust the debtor's obligations, ensuring only that each creditor government takes an equivalent loss. Governments that are not members of the Paris Club are asked to make an equivalent sacrifice as the members. Some do and some do not. The multilaterals never accept less than what governments owe them, although they allow other member states to cover the obligations of over-indebted states, either through direct or indirect donations. Each class of creditors has a natural tendency to seek to minimize its losses and to the degree they are all successful, the debtor country pays the price through a too-small overall debt reduction.

There should be a referee for this process, just as there is a judge in a national bankruptcy court to assess the overall reduction in debt and how it is shared among the different classes of creditors. However, there is none. IMF is meant to advise the debtor government on its overall relief needs, but it admits to advocating "too little, too late" (IMF, 2013). The governing question should be what defines the bottom line for maximum acceptable overall squeezing of the population? For example, should there not be some means by which the coordinating authority in a sovereign debt workout defines and ensures maintenance of a floor of "social protection" by the government. ${ }^{23}$

There have been multiple intergovernmental efforts to devise a comprehensive debt workout mechanism, thus far without agreement, and myriad proposals from civil society, academia and the financial sector have been offered (see Herman, Ocampo \& Spiegel, 2010). Most recently, authors have not only added to writings on the design of the institutional mechanism (e. g., arbitration facility, a court-like forum, IMF action, a model law for guiding the resolution of private claims in national courts), but they have also increasingly considered principles that could guide whatever institutional form the debt workout mechanism might take. At the urging of Argentina, the United Nations General Assembly convened an ad hoc committee of the whole in 2015 that drafted a set of such principles, but most key countries in global finance declined to participate. The principles were adopted by majority vote and did not reflect a consensus, which gave the resulting outcome document very limited international standing (United Nations, 2015b). The problem begs for a more consensual and deliberative process of international debate so as to end up with a set of principles that the major constituencies would embrace. ${ }^{24}$ It also begs for deeper intellectual work to help fashion the principles in a way

23 For an elaboration of the concept of "social protection floor" and its application, see International Labour Organization (2014).

24 For a concrete proposal for such a process, see Herman (2016). 
that goes beyond the relatively pro-creditor legal practice and challenges what should be expected of sovereign debtors and their creditors.

In other words, I am suggesting a topic for Professor Lienau's next book.

Acknowledgements: Comments on an earlier draft of this paper from Yuri Biondi and an anonymous reviewer, as well as conversations with Odette Lienau, are much appreciated. Errors are my fault.

\section{References}

Armendáriz, B., \& Morduch, J. (2010). The economics of microfinance (2nd ed.). Cambridge. Massachusetts: MIT Press.

Barry, C., \& Tomitova, L. (2007). Fairness in sovereign debt. In C. Barry, B. Herman \& L. Tomitova (Eds), Dealing fairly with developing country debt (pp. 41-79). Malden, MA: Blackwell.

Bissell, R., \& Nanwani, S. (2009). Multilateral development bank accountability mechanisms: Developments and challenges. Manchester Journal of International Economics Law, 6(1), 2-55.

Butzbach, O., \& von Mettenheim, K. E. (2015). Alternative banking and theory. Accounting, Economics and Law - A Convivium, 5(2), 105-171.

Christian Aid. (2007). Enough is Enough: the Debt Repudiation Option. Retrieved from http://www.eurodad.org/uploadedfiles/whats_new/reports/debt\%20repudiation\% 20christian\%20aid.pdf.

Gosseries, A. (2007). Should they honour the promises of their parents leaders? In C. Barry, B. Herman \& L. Tomitova (Eds), Dealing fairly with developing country debt (pp. 99-125). Malden, MA: Blackwell Publishing.

Herman, B. (2016). Towards a multilateral framework for recovery from sovereign insolvency. In M. Guzman, J. A. Ocampo \& J. Stiglitz (Eds), Too little, too late: the quest to resolve sovereign debt crises (pp. 206-222). New York: Columbia University Press.

Herman, B., J. A. Ocampo \& S. Spiegel (Eds). (2010). Overcoming developing country debt crises. Oxford: Oxford University Press.

Human Rights Watch (2015). World Bank: Dangerous Rollback in Environmental, Social Protections. August 4. Retrieved from https://www.hrw.org/news/2015/08/04/worldbank-dangerous-rollback-environmental-social-protections.

International Labour Organization. (2014). World social protection report, 2014/15: Building economic recovery, inclusive development and social justice. Geneva: ILO.

International Monetary Fund (2013). Sovereign Debt Restructuring - Recent Developments and Implications for the Fund's Legal and Policy Framework. April 26. Retrieved from https://www.imf.org/external/np/pp/eng/2013/042613.pdf.

Ishikawa, T. (2014). Collective action clauses in sovereign bond contracts and investment treaty arbitration - an approach to reconcile the irreconcilable. Accounting, Economics and Law - A Convivium, 4(2), 63-98. 
Ishikawa, T. (2015). Extraterritorial discovery in aid of execution and state immunity: Case comment on Republic of Argentina v. NML Capital, Ltd., 573 U.S. (2014). Accounting, Economics and Law - A Convivium, 5(2), 173-192.

Mody, A. (Ed.). (1996). Infrastructure delivery: Private initiative and the public good. Washington, D.C: World Bank.

Orwin, C. (2006). Humanitarian military intervention: Wars for the end of history? Social Philosophy and Policy, 23(1) (January), 196-217.

Panizza, U., Sturzenegger, F., \& Zettelmeyer, J. (2009). The economics and law of sovereign debt and default. Journal of Economic Literature, 47(3) (September), 651-698.

Porzecanski, A. (2010). When bad things happen to good sovereign debt contracts: the case of Ecuador. Law and Contemporary Problems, 75(4) (Fall), 251-271.

Sack, A. N. (1927). Les Effets des Transformations des États sur leur Dettes Publiques et Autres Obligations Financières. Paris: Recueil Sirey.

Sinyagina-Woodruff, Y. (2003). Russia, sovereign default, reputation and access to capital markets. Europe-Asia Studies, 55(4) (June), 521-551.

Reuters (2014). Update - China lends Argentina $\$ 7.5$ billion for power, rail projects. July 19. Retrieved from http://uk.reuters.com/article/2014/07/19/argentina-chinaidUKL2NOPT2N220140719.

Salmon, F. (2014). Hedge fund vs. sovereign: How U.S. courts are upending international finance. Foreign Affairs, Snapshot, June 24. Retrieved from https://www.foreignaffairs. com/articles/united-states/2014-06-24/hedge-fund-vs-sovereign.

Shafter, J. (2007). The due diligence model: A new approach to the problem of odious debt. In C. Barry, B. Herman \& L. Tomitova (Eds), Dealing fairly with developing country debt (pp. 275-295). Malden, MA: Blackwell Publishing.

Schumacher, J., Trebesch, C., \& Enderlein, H. (2014). Sovereign defaults in court. Retrieved from SSRN: http://ssrn.com/abstract $=2189997$.

Smith, A. (1776). An inquiry into the nature and causes of the wealth of nations. New York: Modern Library edition, 1937.

United Nations (2015a). Addis ababa action agenda of the third international conference on financing for development, Adopted in Addis Ababa, Ethiopia, July 16 (endorsed by the General Assembly as resolution 69/313 on July 27).

United Nations (2015b). Basic principles on sovereign debt restructuring processes. General Assembly resolution 69/319, adopted September 10.

United Nations Conference on Trade and Development (2012). Principles on Promoting Responsible Sovereign Lending and Borrowing. Geneva, January 10 (http://www.unctad.info/upload/Debt\%20Portal/Principles\%20drafts/SLB_Principles_ English_Doha_22-04-2012.pdf). 